\title{
Congenital lobar emphysema: 30-year case series in two university hospitals*
}

\author{
Enfisema lobar congênito: série de casos de 30 anos em \\ dois hospitais universitários
}

\author{
Daniele Cristina Cataneo, Olavo Ribeiro Rodrigues, Erica Nishida Hasimoto, \\ Aurelino Fernandes Schmidt Jr, Antonio José Maria Cataneo
}

\begin{abstract}
Objective: To review the cases of patients with congenital lobar emphysema (CLE) submitted to surgical treatment at two university hospitals over a 30-year period. Methods: We reviewed the medical records of children with CLE undergoing surgical treatment between 1979 and 2009 at the Botucatu School of Medicine Hospital das Clínicas or the Mogi das Cruzes University Hospital. We analyzed data regarding symptoms, physical examination, radiographic findings, diagnosis, surgical treatment, and postoperative follow-up. Results: During the period studied, 20 children with CLE underwent surgery. The mean age at the time of surgery was 6.9 months (range, 9 days to 4 years). All of the cases presented with symptoms at birth or during the first months of life. In all cases, chest X-rays were useful in defining the diagnosis. In cases of moderate respiratory distress, chest CT facilitated the diagnosis. One patient with severe respiratory distress was misdiagnosed with hypertensive pneumothorax and underwent chest tube drainage. Only patients with moderate respiratory distress were submitted to bronchoscopy, which revealed no tracheobronchial abnormalities. The surgical approach was lateral muscle-sparing thoracotomy. The left upper and middle lobes were the most often affected, followed by the right upper lobe. Lobectomy was performed in 18 cases, whereas bilobectomy was performed in 2 (together with bronchogenic cyst resection in 1 of those). No postoperative complications were observed. Postoperative follow-up time was at least 24 months (mean, 60 months), and no late complications were observed. Conclusions: Although CLE is an uncommon, still neglected disease of uncertain etiology, the radiological diagnosis is easily made and surgical treatment is effective.
\end{abstract}

Keywords: Respiratory system abnormalities; Congenital abnormalities; Pulmonary surgical procedures; Pulmonary emphysema.

\section{Resumo}

Objetivo: Revisar os casos de enfisema lobar congênito (ELC) operados nos últimos 30 anos em dois hospitais universitários. Métodos: Foram revistos os prontuários médicos das crianças com ELC operadas no Hospital das Clínicas da Faculdade de Medicina de Botucatu e no Hospital da Universidade de Mogi das Cruzes entre 1979 e 2009. Dados sobre sintomas, exame físico, achados radiológicos, diagnóstico, tratamento cirúrgico e seguimento pós-operatório mediato e tardio foram analisados. Resultados: Durante o período estudado, 20 crianças com ElC foram submetidas a tratamento cirúrgico. A média de idade dos pacientes no momento da cirurgia foi 6,9 meses (variação, 9 dias a 4 anos). Todos os casos apresentaram sintomas ao nascimento ou nos primeiros meses de vida. Em todos os casos, a radiografia simples de tórax foi importante na definição do diagnóstico. Em casos de dificuldade respiratória moderada, a TC de tórax auxiliou no diagnóstico. Um paciente com desconforto respiratório grave foi diagnosticado erroneamente com pneumotórax hipertensivo e submetido a drenagem torácica. A broncoscopia só foi realizada nos pacientes com dificuldade respiratória moderada e não foram encontrados sinais de anomalias traqueobrônquicas. A abordagem cirúrgica foi realizada através de toracotomia lateral poupadora de músculo. 0 lobo superior esquerdo e o lobo médio foram os mais afetados, seguidos pelo lobo superior direito. A lobectomia foi realizada em 18 casos, enquanto a bilobectomia foi realizada em 2 casos (com ressecção de cisto broncogênico em 1 desses). Complicações pós-operatórias não foram observadas. 0 acompanhamento pós-operatório foi de pelo menos 24 meses (média, 60 meses) e não foram observadas complicações tardias nesta série. Conclusões: 0 ELC é uma doença pouco comum, ainda negligenciada, de etiologia incerta, mas de fácil diagnóstico radiológico e tratamento cirúrgico eficaz.

Descritores: Anormalidades do sistema respiratório; Anormalidades congênitas; Procedimentos cirúrgicos pulmonares; Enfisema pulmonar.

*Study carried out under the auspices of the Graduate Program in the Fundamentals of Surgery, São Paulo State University Botucatu School of Medicine, Botucatu, Brazil, and at the University of Mogi das Cruzes, Mogi das Cruzes, Brazil.

Correspondence to: Daniele Cristina Cataneo. Disciplina de Cirurgia Torácica, Departamento de Cirurgia e Ortopedia, Faculdade de Medicina de Botucatu, Universidade Estadual Paulista, Distrito de Rubião Jr, s/n, CEP 18618-970, Botucatu, SP, Brasil.

Tel. 5514 3811-6091. Fax: 5514 3815-7615. E-mail: dcataneo@fmb.unesp.br

Financial support: None.

Submitted: 22 January 2013. Accepted, after review: 27 May 2013. 


\section{Introduction}

Congenital lobar emphysema (CLE) was first described in 1932, by Nelson, ${ }^{(1)}$ and was so designated in 1951, by Robertson and James. It is a rare disease, its incidence being 1 per 20-30 thousand births. ${ }^{(2)}$ However, the prevalence of CLE during pregnancy is uncertain. ${ }^{(3)}$

The abnormality is defined by hyperinflation of one or more lung lobes in the absence of extrinsic bronchial obstruction. Although the etiology has yet to be fully understood, many authors have reported it as being the result of bronchial abnormalities ${ }^{(4)}$ or alveolar defects. ${ }^{(5)}$ Some theories include bronchial collapse resulting from inadequate cartilaginous support. In 1970, Hislop and Reid ${ }^{(5)}$ found an increase in the number of alveoli in the affected lobe and were the first to describe polyalveolar lobe. Subsequent studies conducted in the 1980s and 1990s re-evaluated and confirmed polyalveolar lobe in CLE. ${ }^{(6)}$ Some Brazilian authors have also reported polyalveolar lobe as the cause of CLE on the basis of histological studies involving alveolar counts, having shown an increase in the number of alveoli per area of lung tissue. ${ }^{(7)}$ It is difficult to differentiate between CLE and hyperinflation resulting from extrinsic bronchial obstruction (lymph nodes, vessels, masses, or cysts) that compresses the bronchus and produces valve obstruction. In such cases, hyperinflation should be designated acquired lobar emphysema; however, more than $50 \%$ of all CLE cases are unrelated to airway abnormalities. The left upper lobe is usually the most frequently affected, followed by the middle and right upper lobes, the lower lobes being rarely affected. It is known that CLE can occur in association with other malformations, especially cardiac malformations, which occur in $20 \%$ of cases. ${ }^{(8)}$

The most common clinical presentation is neonatal acute respiratory distress, which is caused by localized air trapping that compresses the ipsilateral and contralateral normal lungs. The diagnosis is made by clinical examination and routine chest $\mathrm{X}$-rays and can be confirmed by $\mathrm{CT}$. Although bronchoscopy can be an important tool in the differential diagnosis, it is not a primary screening test, being indicated for children whose symptoms appear later, with the objective of excluding acquired bronchial obstruction.

Surgery is the treatment of choice ${ }^{(9)}$ and has been recommended since 1945, when Gross and
Lewis $^{(10)}$ reported the first case of CLE successfully treated by lobectomy. The prognosis is good even when more than one lobe is resected and probably reflects the potential for compensatory alveolar growth in children. ${ }^{(9,11-13)}$

The objective of the present study was to show the clinical and radiographic findings, the approach adopted, and the early and late postoperative outcomes in children with CLE undergoing surgical treatment at either of two university hospitals in the state of São Paulo, Brazil, over a 30-year period.

\section{Methods}

The study was approved by the Research Ethics Committee of the São Paulo State University Botucatu School of Medicine (Protocol no. 268/08-CEP). We reviewed the medical records of children with CLE undergoing surgical treatment between 1979 and 2009 at the São Paulo State University Botucatu School of Medicine Hospital das Clínicas or the Mogi das Cruzes University Hospital.

The diagnosis was confirmed by the presence of respiratory symptoms, typical radiographic findings, and pathological findings. We analyzed the following parameters: age at the onset of symptoms; clinical findings; age at surgery; radiographic findings (on routine chest $\mathrm{X}$-rays and on chest CT scans); bronchoscopic findings (when bronchoscopy was performed); affected lobes; presence of other malformations; type of surgery; pathological findings; and early and late postoperative outcomes. Early postoperative outcome was evaluated on the basis of the following: time to extubation; time to recovery from anesthesia; re-expansion of the remaining lung; and resolution of the symptoms. Late postoperative outcome was evaluated on the basis of respiratory symptoms and findings on routine chest $\mathrm{X}$-rays.

\section{Results}

Between 1979 and 2009, 20 children with CLE underwent surgery. Of those, 15 underwent surgery at the Botucatu School of Medicine Hospital das Clínicas and 5 underwent surgery at the Mogi das Cruzes University Hospital. The time elapsed between the first case and the second case was greater than 8 years. The mean age at surgery was 6.9 months (range, 9 days to 4 years), and 
all of the children were White (Table 1). The age at onset of respiratory symptoms ranged from 0 (i.e., symptoms at birth) to 12 months. Symptoms of respiratory distress (dyspnea, wheezing, and cyanosis) were present in 60\% of the cases, with no evidence of infection. Recurrent pneumonia (fever, cough, tachypnea, and a history of antibiotic therapy) was observed in 50\% of the cases.

The time elapsed between the onset of symptoms and the surgical procedure ranged from 1 day to 36 months. The test that raised the diagnostic suspicion of CLE was a routine chest X-ray, which showed lobar hyperinflation and compression of the ipsilateral and contralateral parenchyma in all cases (Figure 1). A CT scan of the chest was performed in 18 (90\%) of the cases, and the findings consisted of hyperinflation of the affected lobe, contralateral herniation of the affected lobe through the anterior mediastinum, mediastinal shift, and collapse of the healthy lobes due to compression (Figure 2).

Rigid bronchoscopy was performed in 7 children (35\%), although only in those over 6 months of age. Although there was no acute respiratory impairment, most of those children had recurrent pneumonia. In the first case, in 1979, bronchoscopy was performed in a child who was younger than 6 months of age because of the difficulty in establishing the diagnosis.
All of the tests showed that the bronchial tree was within normal limits.

In 1 case, CLE was misdiagnosed as tension pneumothorax at birth, and the child underwent emergency pleural drainage, without success (Figure 3).

In 2 cases, CLE was found in association with other malformations (hydrocephalus in 1 and bronchogenic cyst in 1). In the case of the patient with CLE and bronchogenic cyst, both defects were treated during the same procedure.

The most commonly affected lobes were the left upper lobe (in 7 patients) and the middle lobe (in 7 patients), followed by the right upper lobe (in 6 patients) and the right lower lobe (in 2 patients). Two children had involvement of two ipsilateral lobes.

Lobectomy and bilobectomy were performed in 18 and 2 patients, respectively. In 1 case, bilobectomy was performed in conjunction with bronchogenic cyst resection. In 15 cases, a lateral thoracotomy was performed, and, in 5 cases, thoracotomy was performed via the triangle of auscultation; in all cases, the surgical approach was lateral muscle-sparing thoracotomy. In all procedures, the affected lung herniated through the pleural cavity immediately after it had been opened (Figure 4).

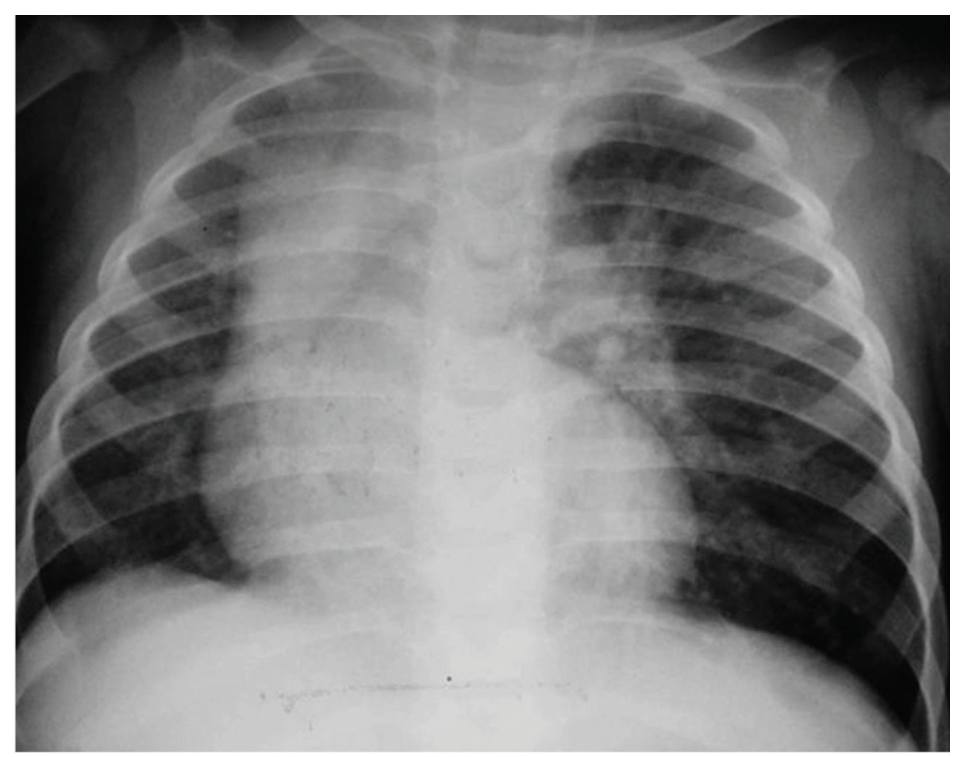

Figure 1 - Chest X-ray showing hyperinflation of the left upper lobe, with compression of the lower lobe and mediastinal shift to the right leading to compression of the entire right lung. 

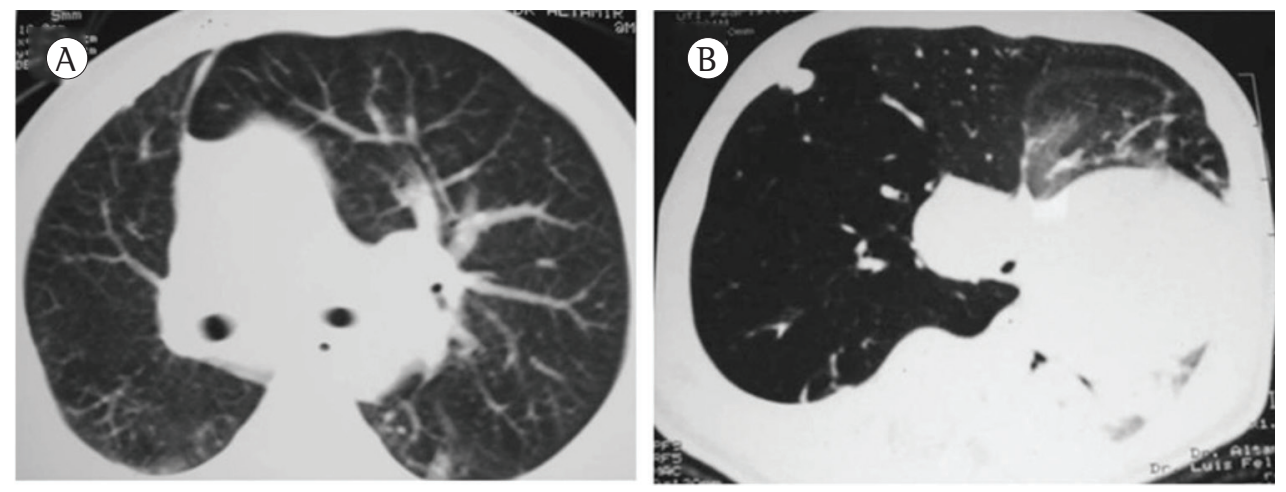

Figure 2 - Chest CT scan showing hyperinflation of the left upper lobe (in A) and right upper lobe (in B), with contralateral mediastinal shift and compression of the contralateral lung in both cases.

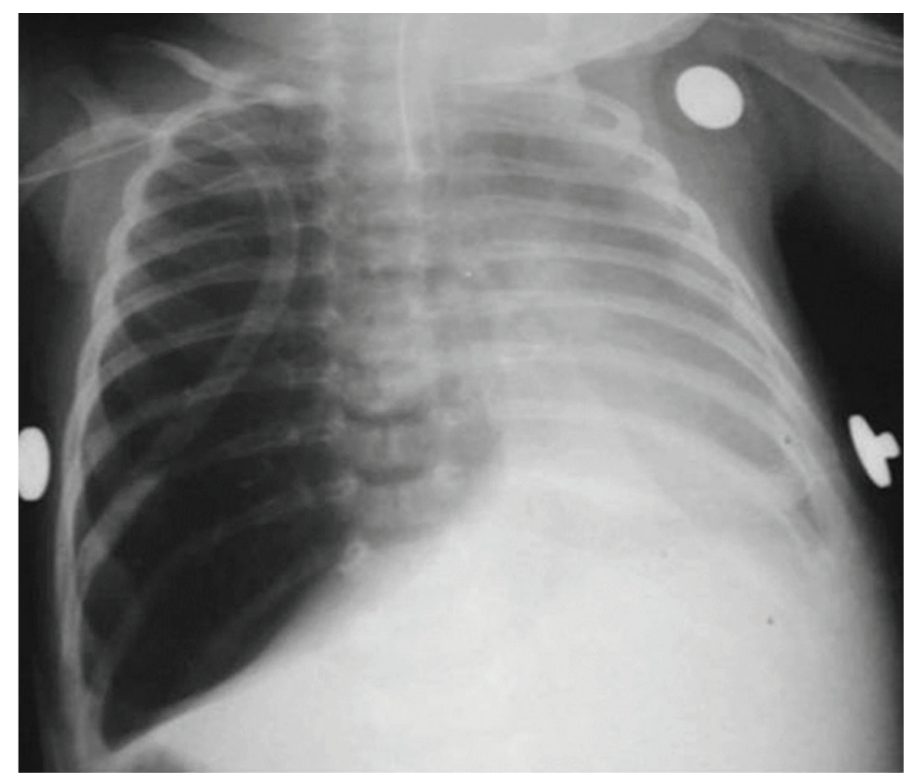

Figure 3 - Chest X-ray of a child with congenital lobar emphysema misdiagnosed as right tension pneumothorax. The child was referred to the facility with a right pleural tube already in place.
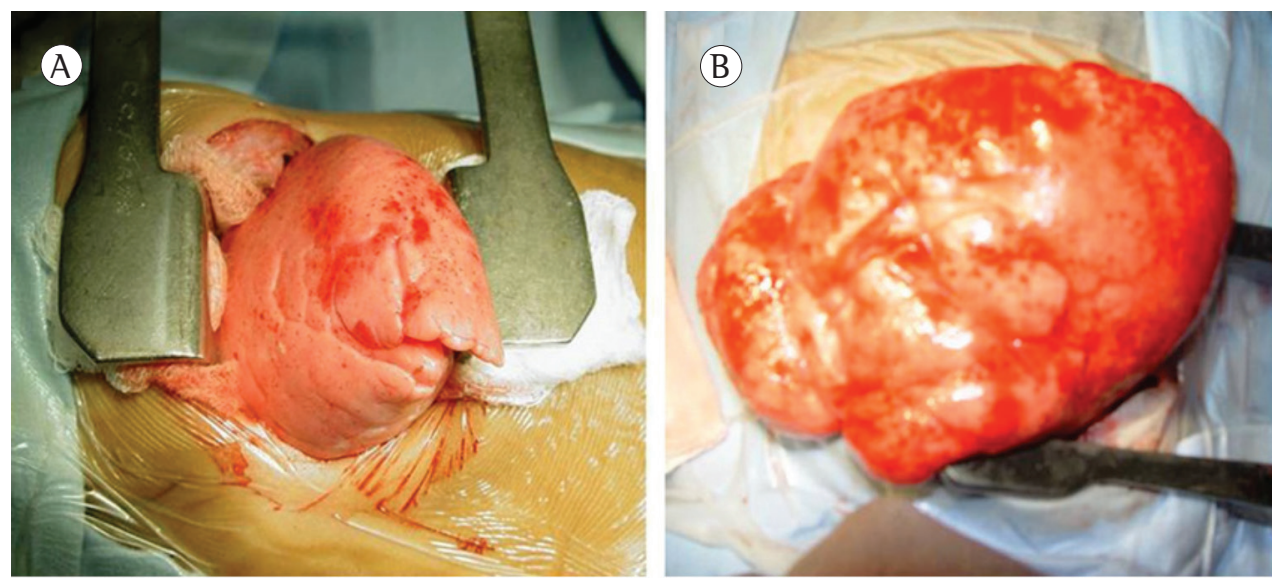

Figure 4 - Hyperinflated left upper lobe (in A) and right upper lobe (in B) with herniation through the chest incision. 
Table 1 - Characteristics of the patients diagnosed with congenital lobar emphysema and treated surgically at either of two hospitals between 1979 and 2009.

\begin{tabular}{|c|c|c|c|c|c|c|c|c|}
\hline Patient & $\begin{array}{c}\text { Year in } \\
\text { which } \\
\text { surgery was } \\
\text { performed }\end{array}$ & Gender & $\begin{array}{c}\text { Age at } \\
\text { symptom } \\
\text { onset }\end{array}$ & Symptoms & $\begin{array}{l}\text { Age at } \\
\text { surgery }\end{array}$ & CT & Bronchoscopy & $\begin{array}{c}\text { Affected } \\
\text { lobes }\end{array}$ \\
\hline 1 & 1979 & Female & 3 months & NARDS & 4 months & No & Normal & ML \\
\hline 2 & 1988 & Male & Neonate & NARDS & 10 days & No & NP & RUL \\
\hline 3 & 1991 & Male & Neonate & NARDS & 9 days & Yes & $\mathrm{NP}$ & LUL \\
\hline 4 & 1995 & Female & Neonate & $\begin{array}{c}\text { Recurrent } \\
\text { pneumonia }\end{array}$ & 3 months & Yes & NP & RLL \\
\hline 5 & 1995 & Female & 12 months & $\begin{array}{c}\text { Recurrent } \\
\text { pneumonia }\end{array}$ & 48 months & Yes & Normal & RUL \\
\hline 6 & 1995 & Male & 4 months & $\begin{array}{c}\text { Recurrent } \\
\text { pneumonia }\end{array}$ & 7 months & Yes & Normal & RUL/ML \\
\hline 7 & 1996 & Female & 2 months & $\begin{array}{c}\text { Recurrent } \\
\text { pneumonia }\end{array}$ & 5 months & Yes & $\mathrm{NP}$ & RUL \\
\hline 8 & 1996 & Male & 30 days & $\begin{array}{l}\text { NARDS and } \\
\text { recurrent } \\
\text { pneumonia }\end{array}$ & 1 months & Yes & $\mathrm{NP}$ & ML \\
\hline 9 & 1999 & Female & Neonate & NARDS & 3 months & Yes & NP & LUL \\
\hline 10 & 2000 & Male & Neonate & NARDS & 1 months & Yes & NP & ML \\
\hline 11 & 2000 & Male & Neonate & $\begin{array}{c}\text { Recurrent } \\
\text { pneumonia }\end{array}$ & 14 months & Yes & Normal & LUL \\
\hline 12 & 2001 & Female & Neonate & NARDS & 2 months & Yes & $\mathrm{NP}$ & LUL \\
\hline 13 & 2001 & Female & Neonate & NARDS & 30 days & Yes & NP & ML \\
\hline 14 & 2002 & Female & Neonate & $\begin{array}{l}\text { NARDS and } \\
\text { recurrent } \\
\text { pneumonia }\end{array}$ & 24 months & Yes & Normal & RLL \\
\hline 15 & 2002 & Male & Neonate & NARDS & 30 days & Yes & NP & RUL/ML \\
\hline 16 & 2003 & Female & Neonate & NARDS & 6 months & Yes & Normal & RUL \\
\hline 17 & 2004 & Male & Neonate & NARDS & 21 days & Yes & $\mathrm{NP}$ & LUL \\
\hline 18 & 2004 & Male & 6 months & $\begin{array}{c}\text { Recurrent } \\
\text { pneumonia }\end{array}$ & 12 months & Yes & Normal & LUL \\
\hline 19 & 2004 & Male & 30 days & $\begin{array}{c}\text { Recurrent } \\
\text { pneumonia }\end{array}$ & 4 months & Yes & $\mathrm{NP}$ & $\mathrm{ML}$ \\
\hline 20 & 2008 & Female & 30 days & $\begin{array}{c}\text { Recurrent } \\
\text { pneumonia }\end{array}$ & 2 months & Yes & $\mathrm{NP}$ & LUL \\
\hline
\end{tabular}

NARDS: neonatal acute respiratory distress syndrome; ML: middle lobe; NP: not performed; RUL: right upper lobe; LUL: left upper lobe; and RLL: right lower lobe. 
A pathological diagnosis of CLE was established in all of the cases, although there were no cartilaginous changes or confirmed polyalveolar lobe in any, and the only possible etiology was a small bronchogenic cyst compressing the upper and middle lobe bronchi.

All of the patients progressed well, being weaned from mechanical ventilation shortly after surgery. Chest tube removal and discharge occurred within up to 4 and 5 days after surgery, respectively. Late postoperative outcomes were satisfactory, and postoperative follow-up time was at least 24 months (mean, 60 months), 3 patients having been followed for more than 10 years. No late complications were observed.

\section{Discussion}

Although the incidence of CLE is possibly underestimated, it ranges from 1:20,000 births to $1: 30,000$ births in the literature, ${ }^{(2)}$ CLE being more common in White boys..$^{(11,14,15)}$ However, in our sample, there was no predominance of CLE in males, and although all of the children were White, the predominance of CLE in White patients no longer seems to hold true, one study having shown a high incidence of CLE in non-White children in Oman. ${ }^{(16)}$

The fact that the incidence of CLE is low has been confirmed by studies conducted in Brazil: at a referral facility for pediatric thoracic surgery in the city of Porto Alegre, 13 patients with CLE underwent surgery over a 10-year period, ${ }^{(17)}$ and at a university hospital in the city of São Paulo, 14 patients with CLE underwent surgery over a 35 -year period. ${ }^{(18)}$ Although the diagnosis of CLE can be made by routine chest $\mathrm{X}$-rays, it continues to be delayed; this suggests that the low incidence of CLE and the difficulty in diagnosing the disease in the presence of infection contribute to delayed diagnosis and treatment, resulting in recurrent and frequent complications. ${ }^{(18)}$ Before the early 1990s, only 2 patients with CLE had undergone surgery at one of the hospitals under study. This shows that the disease was poorly understood in primary health care settings in Brazil.

All of the patients analyzed in the present study had been diagnosed after birth; however, some authors have reported that CLE can be prenatally diagnosed by ultrasound on the basis of the difference in echogenicity and reflectivity between healthy and affected lobes. ${ }^{(15,19,20)}$ Currently, the routine use of prenatal ultrasound allows early diagnosis of all lung malformations. We do not believe that this can increase our sample size, because none of the patients analyzed in the present study had been diagnosed with CLE before birth. However, several other, cystic, malformations were diagnosed by prenatal ultrasound. This might be due to the fact that the sensitivity of ultrasound diagnosis of CLE is lower than is that of ultrasound diagnosis of cystic diseases.

The onset of signs and symptoms of respiratory impairment usually occurs in the first days of life, occurring before the age of 6 months in 90\% of cases, when approximately half of all cases are diagnosed; however, the onset of signs and symptoms of respiratory impairment can occur as late as the age of 5 years. ${ }^{(21)}$ According to the literature, $12 \%$ of all patients with CLE develop severe acute respiratory impairment, a proportion that is consistent with the proportion that we found in our sample.

Radiographic images can sometimes confuse physicians because healthy lobes can appear opaque as a result of their being compressed by the affected lobe. This, in association with symptoms of respiratory distress, can mimic pneumonia, thus delaying diagnosis. The main differential diagnosis on routine chest $\mathrm{X}$-rays is still tension pneumothorax, which is evidenced by the high radiolucency of the affected lung and which can, in association with respiratory distress, lead to unnecessary invasive procedures ${ }^{(6,21,22)}$ that can worsen the condition of patients. In such cases, chest CT is useful in order to confirm the X-ray findings, to determine the affected lobe more accurately, and to exclude other malformations, such as vascular ring, masses, and cysts, which can compress the bronchi. ${ }^{(16)}$

In most of the cases in which the onset of symptoms was immediately after birth, early tracheal intubation and mechanical ventilation contributed to greater air retention in the affected lung, urgent intervention being therefore required. In such cases, some authors have suggested the use of high-frequency ventilation, ${ }^{(23)}$ selective intubation, ${ }^{(24)}$ or endoscopic decompression of the emphysematous lobe ${ }^{(25)}$ for preoperative and perioperative optimization. In cases in which the onset of symptoms is after the sixth month of life or in oligosymptomatic patients, conservative treatment is an option and has been widely discussed in the literature. ${ }^{(26)}$ However, attention 
should be paid to deterioration of respiratory function leading to urgent interventions.

Regarding the affected lobes, our findings were consistent with those reported in the literature. However, the proportion of lower lobe involvement was higher in our case series than in other case series. In 2 cases, more than one lobe was affected. In both cases, the upper right and middle lobes in the right hemithorax were affected. This facilitated the surgical approach-as previously discussed by other authors ${ }^{(15,22)}$-which would have been more difficult had there been bilateral involvement. ${ }^{(27)}$ Some authors have reported that the symptoms are more intense when there is upper lobe involvement than when there is middle lobe involvement. ${ }^{(15,16,22)}$ However, no such difference was found in our sample of patients.

Although CLE has been shown to be significantly associated with cardiac malformations, we found no cardiac malformations in our sample. Our screening for cardiac malformations was carried out exclusively by echocardiography and chest CT because cardiac catheterization and cineangiography ${ }^{(28)}$ seemed extremely invasive and unnecessary.

The intraoperative period is generally made difficult by mechanical ventilation and the use of inhaled anesthetics, such as nitric oxide, which can increase the retention of air in the affected lobe, increasing hyperinflation during the entire procedure and making ventilation and surgical manipulation even more difficult. ${ }^{(8)}$ However, the literature shows that the surgical treatment of CLE is safe, the morbidity and mortality from the procedure being low in most studies. ${ }^{(2,17,18)}$ In our case series, all of the procedures were successful and the surgical approach was lateral muscle-sparing thoracotomy followed by the affected lung being pulled out of the pleural cavity in order to facilitate ventilation. The use of video-assisted thoracoscopic lobectomy ${ }^{(29)}$ for congenital lung malformations has been reported in the literature; however, this surgical approach is difficult in patients with CLE because the pleural cavity is mostly occupied by the affected lobe (which generally remains inflated), and this makes it difficult to create a pneumothorax with the purpose of creating a virtual cavity. Although pain or the cosmetic appearance of the chest wall can justify the use of video-assisted thoracoscopy, none of our patients had such complications.
Although more than 50\% of all CLE cases have no clear etiology, several theories have been proposed to explain the mechanism of air trapping in the emphysematous lung, including the presence of bronchial cartilage dysplasia, ${ }^{(7,30)}$ accumulation of mucus or redundant mucosa leading to valve obstruction, extrinsic compression by aberrant bronchi or vascular structures, infection-related abnormalities, ${ }^{(14)}$ and polyalveolar lobe. ${ }^{(5,6)}$ Contrary to what many authors have reported, we found no cartilaginous changes in the bronchi of the emphysematous lobe. However, such changes cannot be completely ruled out, because it is possible that there was a change in the emergence of the bronchus, which was not resected with the specimen. However, 35\% of the patients who underwent bronchoscopy had no intrinsic or extrinsic central bronchial obstruction. Although bronchoscopy is not a primary screening test, it was used only in patients over 6 months of age, age at which the onset of CLE symptoms is less common. The objective of the procedure was to exclude obstruction by a foreign body or thick secretion plugs and avoid inappropriate surgery, in accordance with the algorithm proposed by Karnak et al. ${ }^{(9)}$ Regarding polyalveolar lobe, although the pathological findings were not consistent with it, we cannot state that it did not occur. Therefore, in one of the cases, the only possible etiology found was bronchogenic cyst compressing the emergence of two lobes.

In conclusion, CLE is an uncommon disease, and it is still difficult to diagnose it in neonatal ICU and infant care settings. Therefore, CLE should be suspected in neonates with respiratory distress. Although the etiology of CLE remains uncertain, the radiological diagnosis is easily made, and surgical treatment is effective and safe.

\section{References}

1. Nelson RL. Congenital cystic disease of the lung: Report of a case. J Pediatr. 1932;1(2):233-8. http://dx.doi. org/10.1016/S0022-3476(32)80105-8

2. Andrade CF, Ferreira HP, Fischer GB. Congenital lung malformations. J Bras Pneumol. 2011;37(2):259-71. http://dx.doi.org/10.1590/S1806-37132011000200017 PMid:21537663

3. Pariente G, Aviram M, Landau D, Hershkovitz R. Prenatal diagnosis of congenital lobar emphysema: case report and review of the literature. J Ultrasound Med. 2009;28(8):1081-4. PMid:19643792

4. Warner JO, Rubin S, Heard BE. Congenital lobar emphysema: a case with bronchial atresia and abnormal bronchial cartilages. Br J Dis Chest. 1982;76(2):17784. http://dx.doi.org/10.1016/0007-0971(82)90032-8 
5. Hislop A, Reid L. New pathological findings in emphysema of childhood. 1. Polyalveolar lobe with emphysema. Thorax. 1970;25(6):682-90. http://dx.doi.org/10.1136/ thx.25.6.682 PMid:5494677 PMCid:472210

6. Tapper D, Schuster S, McBride J, Eraklis A, Wohl ME, Williams A, et al. Polyalveolar lobe: anatomic and physiologic parameters and their relationship to congenital lobar emphysema. J Pediatr Surg. 1980;15(6):931-7. http://dx.doi.org/10.1016/S0022-3468(80)80306-X

7. Giudici R, Leão LE, Moura LA, Wey SB, Ferreira RG, Crotti PL. Polialveolose: patogênese do enfisema lobar congênito? Rev Assoc Med Bras. 1998;44(2):99-105. http://dx.doi.org/10.1590/S0104-42301998000200006 PMid:9699326

8. Moideen 1, Nair SG, Cherian A, Rao SG. Congenital lobar emphysema associated with congenital heart disease. J Cardiothorac Vasc Anesth. 2006;20(2):239-41. http:// dx.doi.org/10.1053/j.jvca.2006.01.019 PMid:16616669

9. Karnak 1, Senocak ME, Ciftci AO, Büyükpamukçu N. Congenital lobar emphysema: diagnostic and therapeutic considerations. J Pediatr Surg. 1999;34(9):1347-51. http://dx.doi.org/10.1016/S0022-3468(99)90009-X

10. Gross RE, Lewis JE. Defect of the anterior mediastinum successful surgical repair. Surg Gynecol Obstet. 1945;80:549-54.

11. Lacquet LK, Lacquet AM. Congenital lobar emphysema. Prog Pediatr Surg. 1977; 10:307-20. PMid:866684

12. Haller JA Jr, Golladay ES, Pickard LR, Tepas JJ 3rd, Shorter NA, Shermeta DW. Surgical management of lung bud anomalies: lobar emphysema, bronchogenic cyst, cystic adenomatoid malformation, and intralobar pulmonary sequestration. Ann Thorac Surg. 1979;28(1):33-43. http://dx.doi.org/10.1016/S0003-4975(10)63389-9

13. Schwartz MZ, Ramachandran P. Congenital malformations of the lung and mediastinum--a quarter century of experience from a single institution. J Pediatr Surg. 1997;32(1):44-7. http://dx.doi.org/10.1016/ S0022-3468(97)90090-7

14. Leape LL, Longino LA. Infantile lobar emphysema. Pediatrics. 1964;34:246-55. PMid:14211085

15. Ozçelik U, Göçmen A, Kiper N, Doğru D, Dilber E, Yalçin EG. Congenital lobar emphysema: evaluation and longterm follow-up of thirty cases at a single center. Pediatr Pulmonol. 2003;35(5):384-91. http://dx.doi.org/10.1002/ ppul.10240 PMid:12687596

16. Thakral CL, Maji DC, Sajwani MJ. Congenital lobar emphysema: experience with 21 cases. Pediatr Surg Int. 2001;17(2-3):88-91. http://dx.doi.org/10.1007/ s003830000506 PMid:11315310

17. Ferreira HP, Fischer GB, Felicetti JC, Camargo Jde J, Andrade CF. Surgical treatment of congenital lung malformations in pediatric patients. J Bras Pneumol. 2010;36(2):175-80. http://dx.doi.org/10.1590/S180637132010000200004 PMid:20485937
18. Costa Júnior Ada S, Perfeito JA, Forte V. Surgical treatment of 60 patients with pulmonary malformations: what have we learned? J Bras Pneumol. 2008;34(9):661-6. PMid:18982202

19. Lacy DE, Shaw NJ, Pilling DW, Walkinshaw S. Outcome of congenital lung abnormalities detected antenatally. Acta Paediatr. 1999;88(4):454-8. http://dx.doi. org/10.1111/j.1651-2227.1999.tb01139.x PMid:10342547

20. Olutoye 00, Coleman BG, Hubbard AM, Adzick NS. Prenatal diagnosis and management of congenital lobar emphysema. J Pediatr Surg. 2000;35(5):792-5. http:// dx.doi.org/10.1053/jpsu.2000.6084 PMid:10813352

21. Man DW, Hamdy MH, Hendry GM, Bisset WH, Forfar J0. Congenital lobar emphysema: problems in diagnosis and management. Arch Dis Child. 1983;58(9):709-12. http://dx.doi.org/10.1136/adc.58.9.709 PMid:6625632 PMCid:1628259

22. Choudhury SR, Chadha R, Mishra A, Kumar V, Singh V, Dubey NK. Lung resections in children for congenital and acquired lesions. Pediatr Surg Int. 2007;23(9):851-9. http:// dx.doi.org/10.1007/s00383-007-1940-8 PMid:17671788

23. Goto H, Boozalis ST, Benson KT, Arakawa K. Highfrequency jet ventilation for resection of congenital lobar emphysema. Anesth Analg. 1987;66(7):684-6. http://dx.doi.org/10.1213/00000539-198707000-00022 PMid:3605681

24. Glenski JA, Thibeault DW, Hall FK, Hall RT, Germann DR. Selective bronchial intubation in infants with lobar emphysema: indications, complications, and long-term outcome. Am J Perinatol. 1986;3(3):199-204. http:// dx.doi.org/10.1055/s-2007-999867 PMid:3718641

25. Phillipos EZ, Libsekal K. Flexible bronchoscopy in the management of congenital lobar emphysema in the neonate. Can Resp J. 1998; 5:219-21. PMid:9707469

26. Mei-Zahav M, Konen O, Manson D, Langer JC. Is congenital lobar emphysema a surgical disease? J Pediatr Surg. 2006;41(6):1058-61. http://dx.doi.org/10.1016/j. jpedsurg.2006.02.011 PMid:16769334

27. Maiya S, Clarke JR, More B, Desai M, Parikh D. Bilateral congenital lobar emphysema: how should we proceed? Pediatr Surg lnt. 2005;21(8):659-61. http://dx.doi. org/10.1007/s00383-005-1425-6 PMid:15918044

28. Roguin N, Peleg H, Lemer J, Naveh Y, Riss E. The value of cardiac catheterization and cineangiography in infantile lobar emphysema. Pediatr Radiol. 1980;10(2):71-4. http://dx.doi.org/10.1007/BF01001742 PMid:7454424

29. Rahman N, Lakhoo K. Comparison between open and thoracoscopic resection of congenital lung lesions. J Pediatr Surg. 2009;44(2):333-6. http://dx.doi.org/10.1016/j. jpedsurg.2008.10.081 PMid:19231529

30. Doull 1J, Connett GJ, Warner JO. Bronchoscopic appearances of congenital lobar emphysema. Pediatr Pulmonol. 1996;21(3):195-7. http://dx.doi.org/10.1002/ (SICI) 1099-0496(199603)21:3<195::AID-PPUL9>3.0.C0;2-P 


\section{About the authors}

\section{Daniele Cristina Cataneo}

Adjunct Professor. Thoracic Surgery Section, Department of Surgery and Orthopedics, São Paulo State University Botucatu School of Medicine, Botucatu, Brazil.

\section{Olavo Ribeiro Rodrigues}

Adjunct Professor. Department of Thoracic Surgery, University of Mogi das Cruzes, Mogi das Cruzes, Brazil.

\section{Erica Nishida Hasimoto}

Doctoral Student. Graduate Program in the Fundamentals of Surgery, São Paulo State University Botucatu School of Medicine, Botucatu, Brazil.

\section{Aurelino Fernandes Schmidt Jr}

Assistant Professor. Department of Thoracic Surgery, University of Mogi das Cruzes, Mogi das Cruzes, Brazil.

\section{Antonio José Maria Cataneo}

Full Professor. Thoracic Surgery Section, Department of Surgery and Orthopedics, São Paulo State University Botucatu School of Medicine, Botucatu, Brazil. 